\title{
Taste Masking of Granulated Acetaminophen by Water Insoluble Ethylcellulose Coating
}

\author{
Amit Bansal, Brian Kreig, Navneet Sharma, James McGinnis, Inderdeep Bhatia, Carlos Paz \\ Perrigo, Allegan, MI 49010, USA
}

Corresponding author: Amit Bansal, 655 Hooker Road, Allegan, MI 49010, USA; E-mail: amit.bansal@perrigo.com; Tel.: +1 7704016528

Received: 1 July 2020 Accepted: 10 Sep 2020 Published: 28 Feb 2021

Citation: Bansal A, Krieg B, Sharma N, McGinnis J, Bhatia I, Paz C. Taste masking of granulated acetaminophen by water insoluble ethylcellulose coating. Folia Med (Plovdiv) 2021;63(1):97-104. doi: 10.3897/folmed.63.e56052.

\begin{abstract}
Introduction: Bitter tasting of drugs leads to non-compliance especially in the case of pediatric patients due to their inability to swallow medication.

Aim: In this study, we aimed to mask the bitter taste of acetaminophen (APAP) particles through coating.

Materials and methods: A pH independent water insoluble ethylcellulose polymer was used to coat the APAP. The coating of water insoluble ethylcellulose on APAP can have a significant impact on the dissolution profile. Various grades of APAP were used for coating; fine grade, Compap L90\% having wide particle size distribution (PSD), and a special granular (SG) APAP 1680 having narrow PSD. Coating was performed using top spray (Vector) for Compap L90\% and SG APAP 1680 grade of APAP.

Results: Bitter taste of SG APAP was masked after spraying dispersion equivalent to a weight gain of $10 \%$ compared to $35 \%$ used for Compap L90\%. Using bottom spray (Wurster coater, GPCP 2.0), coating was performed on SG APAP 1680 grade of APAP by spraying aqueous dispersion of ethylcellulose (Surelease) equivalent to a weight gain of $10 \%$. The scalability of the top spray process was also evaluated in GPCG 30 and bitter taste was masked by using Surelease dispersion equivalent to a weight gain of 6\%. Coated APAP was examined for particle size (PS), particle size distribution (PSD), flowability, and drug release profile. Dissolution was performed using USP apparatus 2 and 4 in phosphate buffer and evaluated for mechanism of drug release. Particle size obtained for coated SG APAP 1680 via top and bottom spray process was $404 \mu \mathrm{m} \mathrm{d}(90)$ and $487 \mu \mathrm{m} \mathrm{d}(90)$ respectively.
\end{abstract}

Conclusions: The results of the study demonstrated the potential of Surelease dispersion in taste masking. The use of SG APAP 1680 having narrow PSD allowed taste masking to achieve at low weight gain without greatly affecting the dissolution profile.

\section{Keywords}

acetaminophen, Surelease, taste masking, Wurster coater

\section{INTRODUCTION}

Taste is an important factor governing compliance especially for pediatric oral delivery. A survey by the American Association of Pediatrics revealed that the unpleasant taste of bitter drugs poses the greatest hindrance to completing treatment in pediatrics. Oral administration of bitter drugs with an acceptable degree of palatability is a key issue for health care providers, especially for pediatric patients. ${ }^{1,2}$
Taste masking is important especially for the dosage forms (e.g. oral disintegrating tablets, chewable tablets, or powder dosage form) that undergo high degree of interaction with the taste buds. Therefore, these dosage forms should have a good taste to improve the palatability and patient compliance. The field of taste masking is continuously evolving, and various technologies such as hot melt extrusion or microencapsulation are used for taste masking. ${ }^{3}$ Most formulations rely majorly on addition of either sweetener 
and/or flavour for taste masking due to the ease of process and high cost-effectiveness. But this approach alone was not very successful for highly bitter and water-soluble drugs and is now used mainly in improving the aesthetic appeal of the product, especially to make it more attractive for pediatric patients. ${ }^{4}$ Another approach to masking the bitter taste of drugs is to coat the bitter drugs using water insoluble polymer coating. Water insoluble coating prevents the direct contact of bitter drugs with the taste buds and thus improves palatability and patient compliance. However, the impact on drug release must be considered, as too much coating will slow down dissolution and could impact product performance. ${ }^{5,6}$ In this study, the coating of water insoluble ethylcellulose polymer was applied on acetaminophen (APAP) to prevent its direct contact with the taste buds. The $\mathrm{pH}$ independent water insoluble polymer ethylcellulose used in these studies was Surelease E-7-19040. ${ }^{7}$ Surelease is an aqueous based dispersion known for its consistent and reproducible taste masking of bitter drugs. It is a non-ionic polymeric system, with low potential for drug interactions. ${ }^{8,9}$ Importantly, due to its water insolubility, it will affect the drug release from the coated dosage form. Therefore, a balance is needed to achieve a dosage form that is adequately coated to mask the bitter taste while not significantly affecting the dissolution profile.

APAP is the first line of drug in the management of pain. It has a bitter taste and can be a challenge in delivery to pediatric population. ${ }^{10}$ An important pre-requisite of powder dosage form is to keep the particle size (PS) below 400 $\mu \mathrm{m}$ to achieve a smooth mouth feel and prevent grittiness. Therefore, initial PS and particle size distribution (PSD) of APAP was critical because it can affect the weight gain needed to hide the surface of bitter APAP. Hence, different grades of APAP with varying physical properties differing in PS or PSD were studied during the developmental stage.

\section{AIM}

The objective of this research work was to develop a taste mask APAP dosage form using a water insoluble polymer without having a significant impact on drug release. Different coating strategies were tested in order to ascertain the suitable coating process. It was found that top spray coating of APAP using Surelease has the potential to mask its bitter taste without having a significant impact on drug release.

\section{MATERIALS AND METHODS}

Three different grades of APAP were used namely, a) fine grade, b) Compap L 90\% (wide PSD, granular and comprised of acetaminophen, pre-gelatinized starch, crospovidone, and stearic acid), and c) special granular (SG) grade 1680 (narrow PSD, 97\% of particles retained on mesh \#80, PS > $180 \mu$ ) (Mallinckrodt pharmaceuticals), Surelease (Colorcon).

\section{Coating of APAP}

Aqueous dispersion of Surelease $(25 \% \mathrm{w} / \mathrm{w})$ was used for coating of APAP. It was diluted to $15 \% \mathrm{w} / \mathrm{w}$ with water and stirred for $1 \mathrm{hr}$ before the start of spraying process. A known amount of APAP was transferred to a Vector instrument (top spray), GPCG 2.0, or GPCG 30 keeping in view of the percentage occupancy in the range of 40-70\%. Prior to the start of spraying, the APAP was fluidized and heated to reach a product temperature of $45-46^{\circ} \mathrm{C}$ and then spraying started. After the completion of spraying, the coated granules were dried at a temperature of $40^{\circ} \mathrm{C}$ for $10 \mathrm{~min}$ and collected in double lined polythene bag. The parameters used during the coating process are shown in Table $\mathbf{1 .}$

Three different grades of APAP were coated with Surelease $v i a$ top spray fluid bed using a Vector FLM-X-5 equipped with top spray nozzle and a Glatt (GPCG 2.0) equipped with a bottom-spray nozzle and Wurster insert. The scalability of the top spray process was also evaluated in a GPCG 30 fluid bed.

\section{Physical characterization of granules}

PSD (uncoated and coated granules) was measured using a Camsizer and Rotap sizer using the sieve size ranging from 45-425 $\mu \mathrm{m}$. The dried granules were analyzed for bulk and tapped density, flow of powder through the $14 \mathrm{~mm}$ orifice funnel.

Table 1. Parameter used for the coating of Compap L90\% and special granular APAP 1680

\begin{tabular}{|c|c|c|c|c|c|c|}
\hline Samples & $\begin{array}{l}\text { Inlet Air } \\
\text { Temp }\left({ }^{\circ} \mathrm{C}\right)\end{array}$ & $\begin{array}{l}\text { Product } \\
\text { Temp }\left({ }^{\circ} \mathrm{C}\right)\end{array}$ & $\begin{array}{l}\text { Exhaust Air } \\
\text { Temp }\left({ }^{\circ} \mathrm{C}\right)\end{array}$ & $\begin{array}{l}\text { Atomizing } \\
\text { Air (bar) }\end{array}$ & $\begin{array}{l}\text { Air Volume } \\
\text { (CFM) }\end{array}$ & $\begin{array}{l}\text { Spray Rate } \\
(\mathrm{g} / \mathrm{min})\end{array}$ \\
\hline $\begin{array}{l}\text { Compap L90\% } \\
\text { (Vector, top spray) }\end{array}$ & $63-70$ & $43-45$ & $38-40$ & 2.5 & $75-120$ & $16-24$ \\
\hline $\begin{array}{l}\text { SG APAP } 1680 \\
\text { Top Spray (Vector) }\end{array}$ & $57-63$ & $42-45$ & $45-46$ & 2.5 & $180-250$ & $15-20$ \\
\hline $\begin{array}{l}\text { SG APAP } 1680 \\
\text { Bottom spray (Wurster) }\end{array}$ & $78-86$ & $41-42$ & $41-43$ & 2.5 & $40-70$ & $8-9$ \\
\hline $\begin{array}{l}\text { SG APAP } 1680 \\
\text { Top Spray GPCG } 30 \text { (scale up batch) }\end{array}$ & $60-66$ & $42-44$ & $45-47$ & 3.0 & $500-750$ & $100-150$ \\
\hline
\end{tabular}




\section{Taste Perception Study}

Taste perception was carried out by a group of human volunteers $(n=5)$, who were blind to the samples being analyzed for taste. The samples of SG APAP 1680 were used for the tasting evaluation. Coated samples obtained via top spray ( $10 \%$ weight gain), bottom spray ( $10 \%$ weight gain) and of scale up batch (6\% weight gain) were evaluated for taste. Uncoated samples were also asked to taste in order to evaluate the impact of coating and to rate them on a rating scale of 1 to 5 . A score of 1 represents extremely poor taste (very bitter), score of 2 (bitter), 3 (slightly bitter), 4 (fair), and 5 (excellent, no taste perceived). The average rating score was then used to characterize the samples. ${ }^{11}$

\section{Dissolution Studies}

In-vitro dissolution studies for the coated granules were carried out using USP Apparatus 2 (Distek, Model 2500, North Brunswick, NJ, USA) and USP apparatus 4 (Sotax Corp. CE7, Westborough, MA, USA). For USP apparatus 2, dissolution was performed using $900 \mathrm{ml}$ of $\mathrm{pH} 5.8$ phosphate buffer at $50 \mathrm{rpm}$ for $120 \mathrm{~min}$. and $150 \mathrm{rpm}$ for another $15 \mathrm{~min}$. Samples were withdrawn at pre-determined time intervals i.e. 5, 10, 15, 30, 60, 90, 120, $135 \mathrm{~min}$ and replaced with equal amount of fresh buffer. The collected samples were analyzed for drug content by Acquity HCLASS / UPLC system using analytical column C18 T3 1.8 um, 2.1 x $100 \mathrm{~mm}$. Coated APAP granules were also analyzed for assay using the UPLC system. For apparatus 4, drug release profile of coated APAP granules was evaluated at a flow rate of $16 \mathrm{~mL} / \mathrm{min}$.

\section{Drug Release Mechanism}

To determine the mechanism of drug release from the dosage form, the drug release profile was fitted to various mathematical models. ${ }^{12,13}$

\section{Zero Order Model}

Drug dissolution is dependent on initial concentration of drug, and the drug is released slowly following "steady state":

$$
\mathrm{Q}_{\mathrm{t}}=\mathrm{Q}_{0}+\mathrm{k}_{0} \mathrm{t}
$$

Where, $Q_{t}$ is the fraction of drug released at time $t ; Q_{0}$ is the initial amount of drug in the solution; $\mathrm{k}_{0}$ is the zero-order release constant.

\section{First-Order Model}

In this model, the drug dissolution declines exponentially, and the release rate is proportional to the residual amount of drug in the dosage form:

$$
\log \mathrm{Q}_{\mathrm{t}}=\log \mathrm{Q}_{0}+\kappa_{1} \mathrm{t} / 2.303
$$

Where, $Q_{t}$ is the fraction of drug released at time $t ; Q_{0}$ is the initial amount of drug in the solution; $\kappa_{1}$ is the first-order release constant.

\section{Hixon-Crowell Model}

This model describes the particles' regular area which is proportional to the cube root of its volume. The equation below explains the release from systems where there is a change in surface area and diameter of particles or tablets.

$$
\mathrm{W}_{0}^{1 / 3}-\mathrm{W}_{\mathrm{t}}^{1 / 3}=\kappa . \mathrm{t}
$$

Where, $\mathrm{W}_{0}$ is the initial amount of drug in dosage form, $\mathrm{W}_{t}$ is the remaining amount of drug in dosage form at time $t$, and $\kappa$ is a constant incorporating the surface-volume reaction.

\section{Korsmeyer-Peppas Model}

This model describes the release kinetics from polymeric dosage forms, when the release mechanism is not well known or when more than one type of release phenomena could be involved:

$$
\mathrm{M}_{\mathrm{t}} / \mathrm{M}_{\infty}=\mathrm{kt}^{\mathrm{n}}
$$

Where, $M_{t} / M_{\infty}$ is the fraction of drug released, $k$ is the kinetic constants characteristic of the drug/polymer, $\mathrm{n}$ is the diffusional exponent for drug release. Dissolution values in the range of $5 \%-60 \%$ were used to fit release data.

\section{RESULTS AND DISCUSSION}

The coating of fine grade of APAP was tested in vector equipment and the process was shut down because the fine APAP did not fluidize properly on application of air flow. Interestingly, it was observed that fine APAP particles possess strong cohesive and adhesive properties, consequently the particles adhere strongly to other APAP particles or to the wall of bowl, and thus prevent fluidization needed for coating. The other grade used for the study was Compap L90\% (granular, wide PSD) and was coated in vector equipment via top spray. Due to its granular property, it fluidized well, and it was found that coating dispersion equivalent to weight gain of $35 \%$ was required to mask its bitter taste. Higher weight gain was required for coating of Compap L90\% due to broad PSD, and thus required more ethylcellulose to cover thick and thin areas. In addition, presence of excess fines leads to both granulation and coating during the spraying process and thus resulted in large variation in PSD shown in Fig. 1A. The coated APAP obtained had larger PSD and particles $>400 \mu \mathrm{m}$ was obtained giving a gritty mouth feel. Then we tested the SG APAP 1680 (granular, narrow PSD), and we found that taste masking was achieved after spraying coating dispersion equivalent to weight gain of $10 \%$ when coating was done in vector equipment (top spray). It was more likely due to the narrow PSD, a uniform coating and taste masking of SG APAP was achieved at lesser weight gain. The PSD obtained following coating was also narrower compared to coated Compap L90\% shown in Fig. $1 B$. 

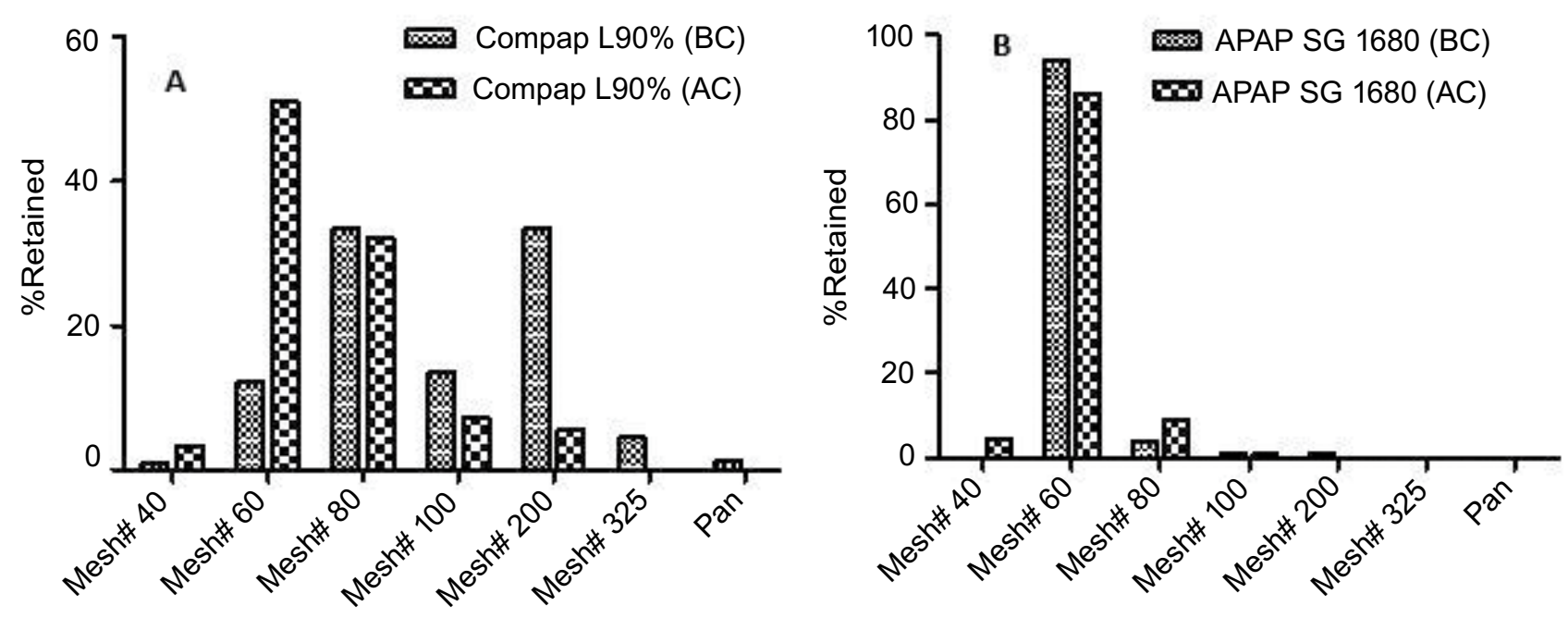

Figure 1. Particle size distribution (PSD) of Compap L90\% and SG APAP 1680 before coating (BC) and after coating (AC) via top spray. The Compap L90\% has wider PSD before and after coating; however, the SG APAP 1680 has narrow PSD before and after coating.

For comparison of coating process, SG APAP 1680 was also coated on Wurster coater equipped with bottom spray nozzle using the amount of coating dispersion equivalent to a weight gain of $10 \%$. It was found that bitter taste was masked, but grittiness was observed in coated SG grade APAP (10\%) due to large PS of $487 \mu \mathrm{m} \mathrm{d}(90)$. We also observed that there was a considerable amount of fines generated during coating of SG APAP 1680 in a Wurster coater and it attributed to the high attrition of APAP particles caused due to the fluidization required for the coating process. The mix of fines and coated SG APAP 1680 was collected following the Wurster coating and sifted through mesh \#100 to get rid of fines. Consequently, it was concluded that coating of SG grade APAP via top spray process is a more reliable process.

In order to further evaluate the scalability of the coating process, we performed the coating of SG grade APAP in GPCG 30 (top spray). An increase in coating efficiency was observed on a scale up batch and bitter taste was masked after spraying dispersion equivalent to a weight gain of $6.0 \%$. Additionally, it also provides the advantage of smaller PS due to lesser weight gain, reduces the cost of finished product due to decrease in coating time and use of less coating material. Smaller PS of coated APAP also confers the benefit of reduced grittiness. The parameters used for coating the SG APAP 1680 granules are shown in Table 1.

The batches prepared by top spray and bottom spray coating of SG APAP 1680 showed a PS of $404 \mu \mathrm{m} \mathrm{d}(90)$ and $487 \mu \mathrm{m} \mathrm{d}(90)$ respectively. The larger PS in case bottom spray coat was attributed to the higher coating efficiency of bottom spray Wurster coating process (Figs 2, 3).

The assay results obtained for formulation prepared by top spray coat and Wurster coat were $101 \%$ and $98.7 \%$ respectively. The flow properties of coated SG APAP granules was important for the final packaging of powder dosage form in pouches. Table 2 showed the physical characteri-

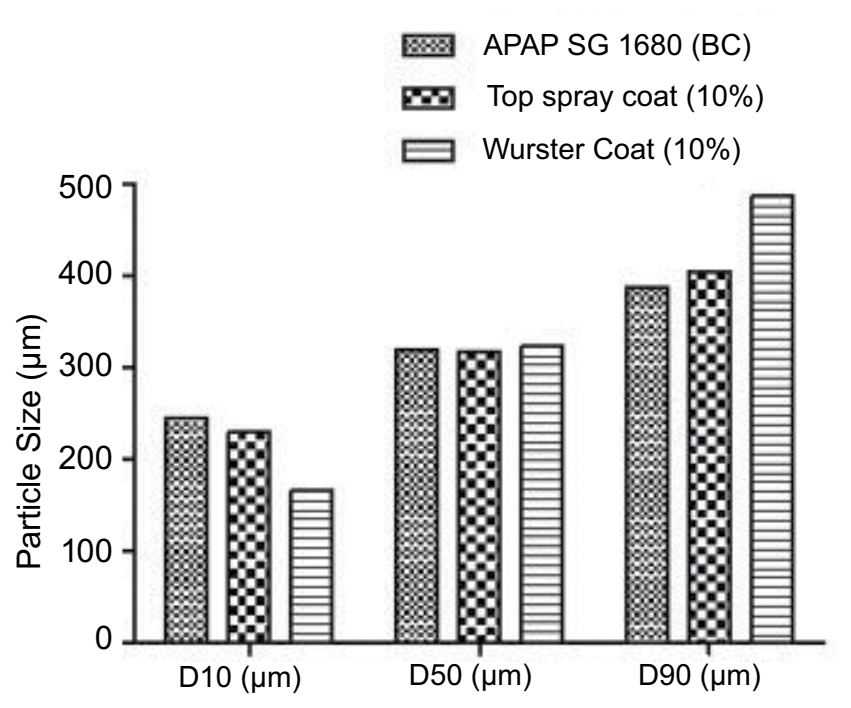

Figure 2. Particle size (PS) comparison of SG APAP 1680 before coating (BC) and after coating of ethylcellulose by top spray and bottom spray process.

zation of Compap L 90\% and SG APAP 1680 before and after the coating of Surelease. Results from the table showed that the bulk density, tapped density, and flow through the orifice changed greatly for Compap L90\% after coating. However, these properties did not change much for SG grade APAP after coating. It is evident from the results that SG APAP 1680 is more suited for taste masking due to its narrow PSD, smaller PS, and better flow over Compap L90\%.

In order to evaluate the efficacy of the coating required to achieve taste masking, a taste perception study was conducted. A scale ranging from 1 to 5 was used to quantify the results of taste perception study. The overall rating of all the coated samples showed a mean rating of 4.7 (Top spray $10 \%$ WG, mean score -4.8 ; Wurster Coat $10 \%$ WG, 


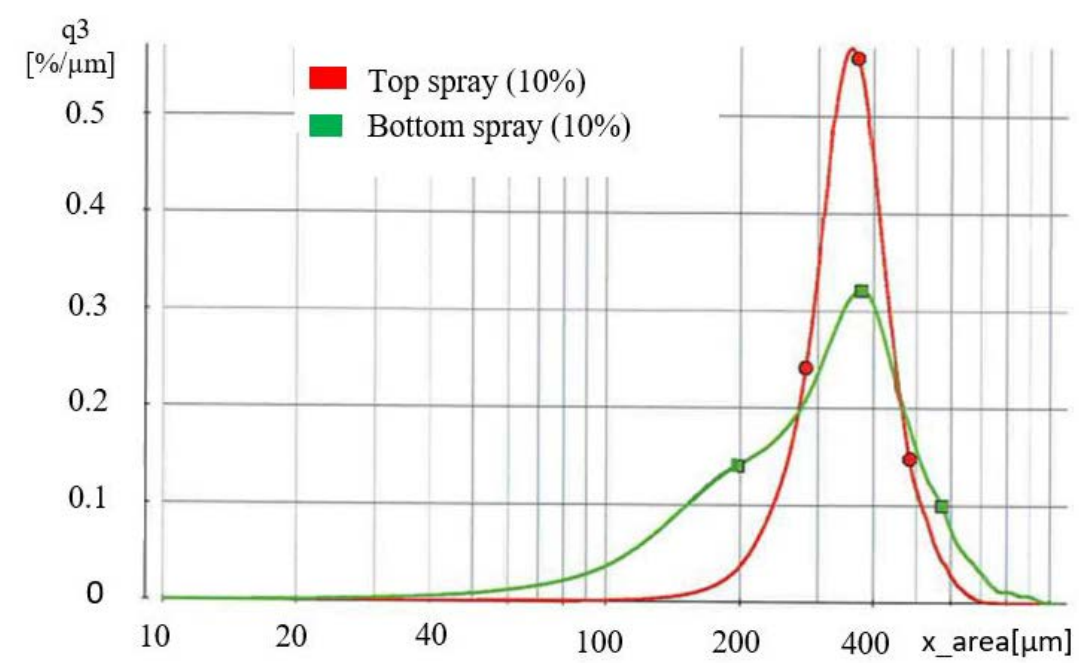

Figure 3. Particle size (PS) of coated SG APAP 1680 via top spray and bottom spray process. The PS of top spray coated APAP was 404 $\mu \mathrm{m} \mathrm{d}(90)$, and bottom spray coated APAP was $487 \mu \mathrm{m} \mathrm{d}(90)$.

Table 2. Physical characterization of Compap L90\% (top spray coat) and SG APAP 1680 (top and bottom spray coat) before and after coating of ethylcellulose

\begin{tabular}{lllllll}
\hline \multirow{2}{*}{ Samples } & \multicolumn{2}{c}{ Bulk density } & \multicolumn{2}{c}{ Tapped density } & \multicolumn{2}{c}{ Flow thru orifice (g/sec) } \\
\cline { 2 - 7 } & Before coating & After coating & Before coating & After coating & Before coating & After coating \\
\hline Compap L 90\% (WG - 35\%) & 0.28 & 0.33 & 0.33 & 0.38 & 11.2 & 15.5 \\
SG APAP 1680 (WG - 10\%) & 0.71 & 0.72 & 0.83 & 0.83 & 25 & 25.5 \\
\hline
\end{tabular}

mean score - 4.8; Top spray 10\% WG GPCG 30, mean score - 4.6) compared to 1.6 in case of uncoated sample. Based on the mean ratings obtained, it can be concluded that the coated samples were taste masked successfully using an aqueous dispersion of ethylcellulose via top spray and Wurster coating.

Figs 4, 5 show the comparative dissolution profile of coated SG APAP 1680 prepared by top spray and bottom spray process. Using apparatus 2 , the drug release for the top sprayed coated SG grade APAP was $83 \%$ in $135 \mathrm{~min}$. However, a noticeable decrease in dissolution profile of coated SG grade APAP was observed in samples coated via bottom spray Wurster coater relative to top spray coat after spraying coating dispersion equivalent to a weight gain of $10 \%$. About $36 \%$ of drug was released in 135 minutes for bottom sprayed coated SG APAP 1680, and it was attributed to over coating of APAP granules resulting from higher coating efficiency of Wurster coating process. Due to overcoating of APAP, the size of coated granules also increased and suggest that taste-masked granules can be obtained at much lesser weight gain and final PS of the coated granules would be much lesser. The results of dissolution profile using apparatus 4 followed the release pattern similar to the results obtained from apparatus 2 .

The dissolution profile of top sprayed coated SG APAP 1680 using the GPCG 30 was slower than the top spray coated batch manufactured in vector equipment. It was observed during the coating process that generation of static charge resulted in increased adhesive and cohesive property leading to adherence of partially coated APAP to the

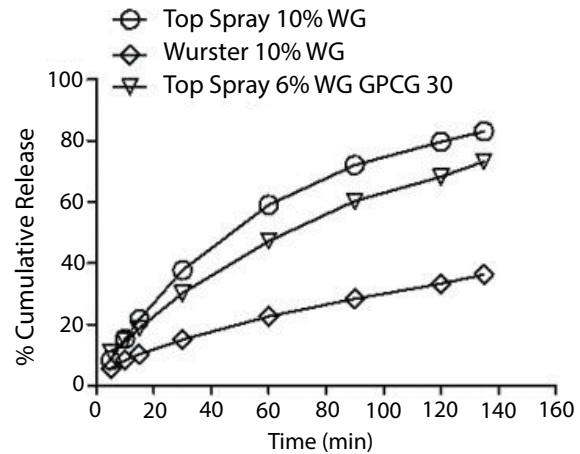

Figure 4. Percent cumulative release profile versus time of coated SG APAP 1680 manufactured by top spray (vector \& GPCG 30 ) and bottom spray (Wurster) coating of ethylcellulose. The dissolution study was performed using apparatus 2 .

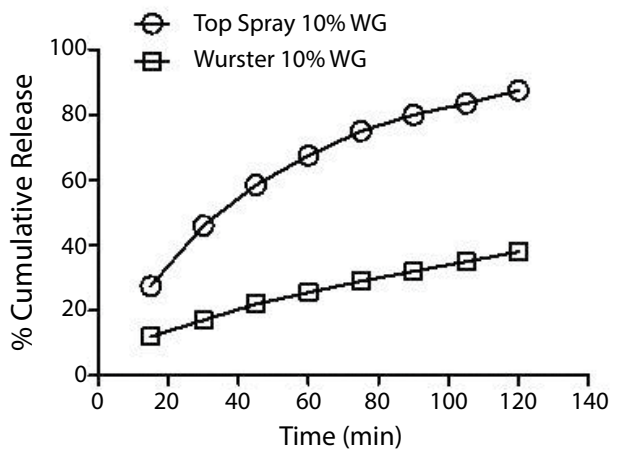

Figure 5. Percent cumulative release profile versus time of coated SG APAP 1680 manufactured by top spray and bottom spray (Wurster) coating of ethylcellulose. The dissolution study was performed using apparatus 4 at a flow rate of $16 \mathrm{~mL} / \mathrm{min}$. 
walls of bowl in GPCG 30. Due to static generation, a major amount of partially coated APAP gran particles sticks to each other or either adheres to the walls of GPCG bowl and did not fluidized well. This would have results in overcoating of remaining APAP granules in the bowl during the spraying and might be responsible for decrease in percent drug release.

Dissolution profiles obtained using apparatus 2 and 4 were analyzed for zero-order, first order, Hixon-Crowell, and Korsmeyer Peppas model in order to evaluate mechanism of drug release. For Korsmeyer Peppas model, the data was analyzed for drug release from $5 \%$ to $60 \% .{ }^{12,13}$ By applying model equation to the dissolution profile obtained from apparatus 2 and 4 , the correlation coefficient $r^{2}$ values obtained are shown in Tables 3, 4, it seemed that all dissolution profiles fit well to the first order and Korsmeyer Peppas model. A good fit to first order indicates the release rate is proportional to the residual amount of drug in the dosage form. The dissolution profile also showed good fit to the Korsmeyer Peppas model and therefore ' $n$ ' values obtained can be used to determine the drug release mechanism. For cylindrical systems, $\mathrm{n}=0.45$ indicates fickian diffusion-controlled drug release, and $n=0.89$ indicates swelling erosion-controlled drug release (case II transport, zero order drug release), Values of $\mathrm{n}$ between 0.45 and 0.89 indicates anomalous transport suggesting superposition of both diffusion and polymer relaxation or erosion mechanism. The values of $n>0.89$ suggesting a super case-II transport indicating increased plasticization at the relaxing boundary (gel layer) and polymer relaxation/erosion. The value of $n$ obtained from dissolution performed in apparatus 2 lies between 0.45 and 0.89 for top spray coated granules having weight gain of $10 \%$ and $6 \%$ indicating anomalous transport. However, the value of $\mathrm{n}$ for bottom spray coated granules with $10 \%$ weight gain was 0.35 i.e. $<0.45$ indicating diffusion-controlled release mechanism. But when the same bottom spray coated granules dissolution was performed in apparatus 4 , the $\mathrm{n}$ value obtained was 0.54 indicating anomalous transport. This difference in $n$ values could be attributed to difference in dissolution mechanism of both apparatuses. While performing dissolution in apparatus 2, the powder dosage form tends to float on the surface of dissolution medium and therefore can affect the drug release profile. In contrast, for apparatus 4 , powder sits on the bed of beads present in dissolution cell and dissolution media enters the cells from the orifice at the bottom of cells and therefore ensure complete wetting of powder dosage form and thus prevents it from floating.

Generally, for the dosage form coated with water insoluble polymer, diffusion through the membrane controlled the overall release of drug. During the spraying process, granules were coated with Surelease, layer over the layer and pores in the layers gets blocked, and thus impede the release of drug. It is evident from the results of Wurster coat batch with $10 \%$ weight gain that the coating load had a major effect on the release rate of drug. However, in case of granules coated via top spray, layer of coating was not as thick as in case of Wurster coat batch indicating from the smaller PS $404 \mathrm{um}, \mathrm{d}(90)$ and faster drug release profile. Therefore, drug release mechanism deviates from diffusion and followed superposition of both diffusion and erosion mechanism.

Due to the use of water insoluble ethylcellulose polymer, an important challenge is not to compromise the dissolution profile. Overcoating may lead to slowing down the release of drug, therefore careful attention is needed not to overcoat the APAP granules. A large-scale batch will be manufactured, and samples will be collected by spraying the coating solution equivalent to $5 \%$ weight gain and evaluated for dissolution profile and taste. To allow the fast release of drug, we will add pore former that can facilitate the release of drug through the pores created in the polymer coat. The purpose to make the drug release faster is to match dissolution profile of our test formulation with innovator formulation (data not shown). And we believe that decrease the weight gain to $5 \%$ and addition of pore former in the polymer coat would result in matching the dissolution profile with the innovator formulation.

Table 3. Coefficients of determination $\left(\mathrm{r}^{2}\right)$ obtained from the dissolution profile of coated SG APAP 1680 using apparatus 2

\begin{tabular}{llllll}
\hline Formulation & Zero Order & First Order & Hixon-Crowell & Korsmeyer-Peppas & $\mathrm{n}$ \\
\hline & $\mathrm{r}^{2}$ & $\mathrm{r}^{2}$ & $\mathrm{r}^{2}$ & $\mathrm{r}^{2}$ & 0.79 \\
\hline Top spray 10\% WG & 0.9377 & 0.9967 & 0.9845 & 0.9961 & 0.35 \\
Wurster 10\% WG & 0.9623 & 0.9805 & 0.9751 & 0.9997 & 0.60 \\
Top spray 6\% WG & 0.9606 & 0.9966 & 0.9897 & 0.9937 & \\
\hline
\end{tabular}

Table 4. Coefficients of determination $\left(\mathrm{r}^{2}\right)$ obtained from the dissolution profile of coated SG APAP 1680 using apparatus 4

\begin{tabular}{llllll}
\hline Formulation & Zero Order & First Order & Hixon-Crowell & Korsmeyer-Peppas & $\mathrm{n}$ \\
\hline & $\mathrm{r}^{2}$ & $\mathrm{r}^{2}$ & $\mathrm{r}^{2}$ & $\mathrm{r}^{2}$ & 0.65 \\
\hline Top spray 10\% WG & 0.887 & 0.9962 & 0.9754 & 0.9932 & 0.54 \\
Wurster 10\% WG & 0.9419 & 0.9710 & 0.9623 & 0.9784 & \\
\hline
\end{tabular}




\section{CONCLUSIONS}

This study demonstrates the utility of ethylcellulose in masking the bitter taste of bitter APAP. Among the three grades of APAP used for evaluation, SG grade of APAP was found to be suitable for taste masking due to its initial PS, narrow PSD, and granular property. The physical properties of this grade allow it to be coated through various processes at minimal weight gain to achieve a taste masked product. The top spray coating of SG APAP 1680 was not as efficient as the Wurster approach but was preferred because Wurster process generate more fines during the coating process and slowed down the drug release. Further process optimization work could be done with the Wurster process to identify a percentage coating that allows for taste masking without impacting drug release.

The scalability of coating in a GPCG 30 has been found to enhance the efficacy of coating process. Overall, the taste masking of bitter SG grade APAP 1680 by coating Surelease via top spray has the potential to improve patient compliance and can facilitate effective treatment in case of pediatrics.

\section{Acknowledgements}

The authors are grateful to the Perrigo Company for providing the resources including acetaminophen, Surelease, coating equipment, and Allegan county facility to perform the experiments.

\section{REFERENCES}

1. Ayenew Z, Puri V, Kumar L, et al. Trends in pharmaceutical taste masking technologies: a patent review. Recent Pat Drug Deliv Formul 2009; 3(1):26-39.

2. Georgieva YZ, Pilicheva BA, Kokova VY, et al. Taste masking of enalapril maleate by the precipitation method. Folia Med (Plovdiv) 2019; 61(3):426-34
3. Taste-Masking - Pharmaceutical Taste-Masking Technologies. Drug Development and Delivery. Published June 30, 2015. Available from: https://drug-dev.com/taste-masking-pharmaceuticaltaste-masking-technologies/ [Accessed May 12, 2020].

4. Sohi H, Sultana Y, Khar RK. Taste masking technologies in oral pharmaceuticals: recent developments and approaches. Drug Dev Ind Pharm 2004; 30(5):429-48.

5. Zheng X, Wu F, Hang Y, et al. Developments in taste-masking techniques for traditional Chinese medicines. Pharmaceutics 2018; 10(3):157.

6. Friend DR, Ng S, Sarabia SR, et al. Taste-masked microcapsule compositions and methods of manufacture. [Internet] US6139865A, October 1, 1996. Available from: https://patents.google.com/patent/ US6139865A/en

7. Kazlauske J, Cafaro MM, Caccavo D, et al. Determination of the release mechanism of Theophylline from pellets coated with Surelease - A water dispersion of ethyl cellulose. Int J Pharm 2017; 528(1):345-53.

8. DeMerlis CC, Schoneker DR, Borzelleca JF. A subchronic toxicity study in rats and genotoxicity tests with an aqueous ethylcellulose dispersion. Food Chem Toxicol 2005; 43(9):1355-64.

9. Hughes KW, Mehta RY, Cunningham CR, et al. Evaluation of acetaminophen particle size and crystal morphology on taste-masking performance from coated granules and chewable tablets. Int J Pharm 2016; 511(2):1134.

10. Albertini B, Cavallari C, Passerini N, et al. Characterization and taste-masking evaluation of acetaminophen granules: comparison between different preparation methods in a high-shear mixer. Eur J Pharm Sci Off J Eur Fed Pharm Sci 2004; 21(2-3):295-303.

11. Patel AR, Vavia PR. Preparation and evaluation of taste masked famotidine formulation using $\mathrm{drug} / \beta$-cyclodextrin/polymer ternary complexation approach. AAPS Pharm Sci Tech 2008; 9(2):544-50.

12. Sadeghi F, Ford JL, Rubinstein, et al. Comparative study of drug release from pellets coated with HPMC or Surelease. Drug Development and Industrial Pharmacy 2000; 26(6):651-60.

13. Oliveira PR, Mendes C, Klein L, et al. Formulation development and stability studies of norfloxacin extended-release matrix tablets. BioMed Res Int 2013; 2013:716736. 


\title{
Маскировка вкуса гранулированного ацетаминофена покрытием из нерастворимой этилцеллюлозы
}

\author{
Амит Бансал, Брайан Крейг, Навнийт Шарма, Джеймс Мак Гинис, Индардийп Батия,
} Карлоз Паз

Периго, Алеган, МИ 49010, САЩ

Адрес для корреспонденции: Амит Бансал, ул. „Хукар Роуд“№ 655, Алеган, МИ 49010, США; E-mail: amit.bansal@perrigo.com; Тел.: +17704016528

Дата получения: 1 июля 2020 Дата приемки: 10 сентября 2020 Дата публикации: 28 февраля 2021

Образец цитирования: Bansal A, Krieg B, Sharma N, McGinnis J, Bhatia I, Paz C. Taste masking of granulated acetaminophen by water insoluble ethylcellulose coating. Folia Med (Plovdiv) 2021;63(1):97-104. doi: 10.3897/folmed.63.e56052.

\section{Резюме}

Введение: Горький вкус лекарств приводит к несоблюдению режима терапии, особенно в случае педиатрических пациентов, из-за невозможности проглотить лекарство.

Цель: В этом исследовании нашей целью было замаскировать горький вкус частиц ацетаминофена (АРАР) через оболочку.

Материалы и методы: Для покрытия АРАР использовали рН-независимый водонерастворимый полимер этилцеллюлозы. Покрытие из нерастворимой этилцеллюлозы на АРАР может оказывать значительное влияние на профиль растворения. Для покрытия использовались разные классы APAP: мелкие гранулы, Сотрар L90\% с широким гранулометрическим составом (PSD) и специальные гранулы (SG) APAP 1680 с низким PSD. Покрытие наносили поверхностным распылением (Vector) для классов APAP Compap L90\% и SG APAP 1680.

Результаты: Горький вкус SG APAP, замаскированный после распыления дисперсии, эквивалентен увеличению веса на $10 \%$ по сравнению с 35\% у Compap L90\%. Используя распыление снизу (устройство для нанесения покрытий Wurster, GPCP 2.0), на классы SG APAP 1680 APAP наносили покрытие путём распыления водной дисперсии этилцеллюлозы (Surelease), эквивалентной увеличению веса на $10 \%$. Способность к росту описанного выше процесса распыления также оценивали с помощью GPCG 30, а горький вкус скорректировали с помощью дисперсии Surelease, эквивалентной увеличению веса на 6\%. APAР с покрытием тестировали на размер частиц (PЧ), гранулометрический состав (PSD), текучесть и профиль высвобождения лекарственного средства. Растворение проводили с помощью аппаратов 2 и 4 USP в фосфатном буфере и оценивали механизмы высвобождения лекарственного средства. Размер частиц для SG APAP 1680 с покрытием, полученного методом распыления снизу и сверху составлял $404 \mu \mathrm{m} \mathrm{d}(90)$ и $487 \mu \mathrm{m} \mathrm{d}(90)$, соответственно.

Заключение: Результаты исследования показали потенциал дисперсии Surelease в коррекции вкуса. Использование SG APAP 1680 с узким PSD позволило коррекции вкуса достичь небольшого увеличения веса без серьёзного влияния на профиль растворения.

\section{Ключевые слова}

ацетаминофен, Surelease, маскировка вкуса, технология для нанесения покрытия Wurster 